\title{
IN Situ dm, FIBER DEGRADATION AND IN VITRO GAS PRODUCTION OF SEA WATER IRRIGATED GRASS (Spartina alterniflora Lois.) BY ARABIAN CAMEL
}

\author{
M. H. Abdel Gawad ${ }^{1}$ and G. A. Alhadrami ${ }^{2}$ \\ 1- Department of Animal Production, Faculty of Agriculture, Cairo University, \\ Egypt, 2- Department of Arid Lands Agriculture, College of Food and Agriculture, \\ U.A.E. University, Al-Ain, United Arab Emirates
}

\section{SUMMARY}

The objective of this study was to evaluate the nutritive value of spartina grass (Spartina alterniflora) irrigated with sea water. Three adult cannulated she-camels were used to determine DM and fiber degradation. Rhodesgrass (Chloris gyana); irrigated with fresh water was used as a control. Spartina grass was irrigated with sea water using flood irrigation system. Samples of spartina grass were collected from Dhabiyah Research Station. Treatments were: 1) Spartina grass (no washing; SPT1); 2) Spartina grass (washed with fresh water after cutting; SPT2); 3) Spartina grass washed with sea water before cutting: SPT3); 4) Spartina grass washed with sea water before and after cutting; SPT4); 5) Spartina grass (steam treated at $r . .{ }^{\circ} \mathrm{C}$, 17 Bar for 2 min.; SPT5). Chemical analyses indicated that Rhodes grass and spartina grass had similar protein content. Ash content of spartina (SPT1) was $35.3 \%$ vs. $9.2 \%$ in Rhodes grass. As a result of washing and steam treatment, the total ash content was reduced in SPT2, SPT4 and SPT5 to (24.4, 24.8 and 25.6\%), respectively. Also, sodium and hemicellulose of steam treated spartina deceased to 4.0 and $7.3 \%$, respectively. On the other hand, ADIN percentage significantly increased. Dry matter degradation up to $72 \mathrm{hr}$ of incubation was significantly $(P<.05)$ higher in SPT2 and SPT4 compared to the other treatments. However, in vitro gas production ( $\mathrm{ml} / 0.2 \mathrm{~g} \mathrm{DM}$ ) of Rhodes grass was significantly higher than spartina grass treatments after 72 hrs of incubation. It could be concluded that spartina grass has a potential as a source of forage if washed with fresh water after cutting or with sea water before and after cutting.

Keywords: Spartina grass, fiber degradation, gas production, Arabian camels

\section{INTRODUCTION}

Because of the difficulty in meeting forage demand from cultivation in arid and semi arid lands as a result of drought, salinity and/or desertification (most of Arabic region), previous studies have underlined the potential role of halophytes (salt tolerant plants) as an alternative source of forage for livestock (Ahmed 1993, Garduno 1993, Katting et al., 1993, Riley and Abdalla, 1993 and Ben Salem et al., 1994). Spartina grass (Spartina alterniflora) classified as perennial grass that belongs to $\mathrm{C} 4$ halophyte (euhalophyte), tolerate salinity up to $58 \mathrm{ds} / \mathrm{m}$ (more than sea

Issued by The Egyptian Society of Animal Production 
water salinity) and yields about 9 tons green forage/acre (Aronson, 1989). This grass has been introduced into United Arab Emirates by Zaied International Agricultural and Environmental Program (Lieth and Lieth, 1993). This grass is of interest because it grows well under harsh environment of drought and salinity and might have a potential as forage for livestock. Lieth and Lieth (1993) stated that Spartina alterniflora successfully grows under $3.5 \%$ salinity which equals to sea water. Prediction of animal performance on marginal quality roughages by using simple, reliable and cheap techniques becomes very important in animal nutrition. Measurement of the degradability of roughages incubated in nylon bags in the rumen (in sacco method) is now widely used and reported to be generally well correlated with animal performance (Ørskov, 1989). In addition, Menk and Steingass (1988) developed the gas production technique (in vitro) to evaluate the nutritive value of foodstuffs.

High salt content of halophytes has been reported to limit their use as forage, however, there are some means to overcome such problem. Blending with other components in prepared feed mixtures is one of the possible solutions (O'leary and Gleen, 1994). Salt tolerant plants have different mechanisms to get rid of slat stress resulting from growth in saline habitat or irrigation with saline water. Spartina grass follows definite mechanism by secreting salts through salt glands or bladders that are located on the leaf surface (Hamad, 2000), and this salt could be easily removed by washing with running water. Ash content of such grass is almost one-third of the dry matter content. The main objective of this study was to alleviate salt stress by removing the accumulated salt crystals on grass leaves through washing and to study its impact on in situ degradation of dry matter, crude protein and fiber fractions and in vitro gas production compared with the commonly used grass Rhodes grass (Chloris gyana).

\section{MATERIALS AND METHODS}

\section{Study area}

The evaluated slat marshes grass (Spartina alterniflora) was collected from Aldabeia Research Station of Zayed International Agricultural and Environmental Research program, UAE University, UAE. The grass was grown under $3.5 \%$ salinity and harvested at approximate $45-50 \mathrm{~cm}$ height.

\section{Animals and Treatments}

Three adult dromedary she-camels weighting an average $450 \mathrm{Kg}$ fitted with first compartment cannulae were used to investigate the in situ nutrient degradability comparison among RH; Rhodes grass hay (fresh water irrigated; the common roughage imported from Saudia Arabia) and different treatments of Spartina grass hay which could be classified as follows: SPT1; spartina grass hay, as is (not washed), SPT2; spartina grass hay washed with fresh water after cutting, SPT3; spartina grass hay washed with sea water before cutting, SPT4; spartina grass hay washed with sea water before and after cutting, and SPT5; SPT4 + steam pressure treatment $\left(200^{\circ} \mathrm{C} / 17\right.$ par $/ 4$ min. $)$.

\section{Experimental procedures}

A.O.A.C., 1984 procedures were followed for determining the proximate analysis; ash, CP and EE. The non structural carbohydrates which include NDF, 
ADF, cellulose, lignin and hemicellulose (by difference; NDF-ADF) and also the acid detergent insoluble nitrogen (ADIN) were determined according to Georing and Van Soest (1970. Silica was determined as the residue after the crucible has been combusted for lignin determination. Wide range of mineral analysis $(\mathrm{Na}, \mathrm{K}, \mathrm{Ca}, \mathrm{Mg}$ in $\%$ and $\mathrm{Cu}, \mathrm{Fe}, \mathrm{Mn}, \mathrm{Zn}, \mathrm{Cd}, \mathrm{Pb}, \mathrm{P}$ in $\mathrm{Mg} \%$ ) was measured according to Chapman and Pratt (1961. Ruminal disappearance of DM, CP, NDF and ADF was determined using artificial fiber bags technique as described by Mehrez and Ørskov (1977. Five gram air dry samples milled through a Wiley mill (Arther H. Thomas, Philadelphia, PA) to pass a $2 \mathrm{~mm}$ screen were inoculated in the rumen of three she-camels as animal replicates. The size of the bag was $170 \times 100 \mathrm{~mm}$ with an average pore size of $50 \mu \mathrm{m}$. The bag was made from nylon filter cloth. Camels were fed ad libitum Rhodes or spartina grass hay supplemented with $4 \mathrm{Kg}$ concentrate diet for three weeks, followed by the incubation period. Duplicate sample bags at each time were inoculated in each camel for seven incubation times $(6,12,24,48,72,96$ and 120 hours) in reverse order before the morning feeding. Bags were suspended using a nylon cord tied to the cannula cap. The cord had a weight at the other end to aid in submersion of bags into the ventral portion of the first compartment. Bags were removed simultaneously and washed immediately with tap water until the water drains was clean. Ten bags were oven-dried at $55^{\circ} \mathrm{C}$ for $48 \mathrm{~h}$ and weighed to determine DM. Residue was removed from the bags and duplicates at each point of time were composited and analyzed for $\mathrm{CP}$, ADF and NDF. For in vitro gas production measurement, rumen liquor was obtained from three she-camels on the same diet previously mentioned and added to buffer solution at ratio (1:2) as described by Menke et al.(1979). After weighing, about $0.20 \mathrm{~g}$ of air-dry and milled $(1 \mathrm{~mm})$ sample was into calibrated glass syringes $(100 \mathrm{ml})$ with pistons were lubricated with vaseline to ease the sliding of pistons and prevent gas escape. The syringes were rewarmed at $40^{\circ} \mathrm{C}$ before dispending $30 \mathrm{ml}$ of rumen liquor and buffer mixture followed by incubation in shaking water bath at $39^{\circ} \mathrm{C}$. Readings were recorded after incubation periods of $3,6,12,24,48$, and $72 \mathrm{hr}$. Duplicates of each sample were used for each cannulated animal run.

\section{Statistical analysis}

The Completely Randomized Design (RCD); one factor was the statistical design used. The data pooled was statistically manipulated using MSTAT-C (Nissen, 1989) according to the following model, $Y_{i j}=\mu+T_{i}+e_{i j}$, were $\mu$ is the overall means of $Y_{i j}, T_{i}$ is the effect of treatment and $e_{i j}$ is the experimental error. Duncan's Multiple Range Test was used at alpha level $<0.5$ to separate and compare means.

\section{RESULTS AND DISCUSSION}

\section{Chemical Composition}

As shown in Table 1, ash content of spartina grass hay (SPT1) is much higher compared to Rhodes grass hay (almost 4 times). While, ash content of the other treated spartina exceeds Rhodes grass by 2 to 3 times. This means that washing of spartina grass either with fresh water or sea water after cutting or steam treatment was a good means of getting rid of most of the ash content, from $35.7 \%$ to $16.9 \%$, with $28 \%$ average reduction. This result confirmed that found by Gleen et al., 1992. 
Table 1. Chemical composition and mineral content (DM basis) of Rhodes grass hay and spartina grass hay

\begin{tabular}{lcccccc}
\hline \multicolumn{1}{c}{ Item } & Rhodes & SPT1 & SPT2 & SPT3 & SPT4 & SPT5 \\
\hline Chemical Composition, \% & & & & & \\
Ash & 9.2 & 35.3 & 24.4 & 30.3 & 24.8 & 25.6 \\
CP & 8.2 & 8.6 & 8.4 & 7.6 & 8.7 & 8.2 \\
EE & 0.5 & 1.0 & 1. & 1.0 & 2.0 & 3.3 \\
ADF & 33.9 & 25.0 & 30.5 & 27.9 & 28.8 & 33.9 \\
NDF & 41.1 & 48.7 & 58.8 & 53.0 & 58.2 & 41.1 \\
Cellulose & 29.2 & 18.7 & 23.8 & 21.0 & 22.0 & 26.5 \\
Hemicellulose & 7.2 & 23.8 & 28.6 & 25.1 & 29.4 & 7.3 \\
Lignin & 8.7 & 3.6 & 3.8 & 3.8 & 4.4 & 7.3 \\
Silica & 1.1 & 1.6 & 2.0 & 1.6 & 0.8 & 0.6 \\
ADIN & 3.2 & 3.0 & 3.0 & 2.8 & 3.1 & 6.4 \\
Mineral Content: & & & & & & \\
Sodium, \% & 0.9 & 8.9 & 5.5 & 7.1 & 6.5 & 4.0 \\
Potassium, \% & 0.8 & 0.8 & 0.8 & 0.8 & 0.9 & 0.8 \\
Calcium, \% & 0.6 & 1.0 & 1.0 & 1.3 & 0.9 & 0.9 \\
Magnesium, \% & 0.3 & 0.7 & 0.7 & 0.9 & 0.7 & 0.7 \\
Phosphorus, mg\% & 42.2 & 23.8 & 28.0 & 26.04 & 22.0 & 31.5 \\
Copper, mg\% & 10.0 & 10.0 & 10.0 & 10.0 & 10.0 & 10.0 \\
Iran, mo\% & 255 & 295 & 235 & 335 & 230 & 240 \\
Manganese, mg\% & 20.0 & 60 & 65 & 60 & 50 & 50 \\
Zinc, mg\% & 40 & 20 & 30 & 40 & 60 & 80 \\
Cadmium, mg\% & 0.0 & 0.0 & 0.0 & 0.0 & 0.0 & 0.0 \\
Lead, mg\% & 45 & 55 & 50 & 45 & 40 & 45 \\
\hline
\end{tabular}

Crude protein content of Rhodes grass hay and the other treated spartina is almost the same and matched the findings of Leith and Leith (1993). Ether extract of SPT1, SPT2, SPT3 is higher than Rhodes grass hay by 2 to 4 folds and by 6 to 7 folds in SPT5 compared to Rhodes grass hay $(\mathrm{RH})$. Concerning fiber content; the acid detergent fiber (ADF) of Rhodes grass hay $(\mathrm{RH})$ was higher compared with that determined in SPT1, SPT2, SPT3 and SPT4 and the fractions of ADF (cellulose and lignin) followed the same trend. On the other hand, neutral detergent fiber (NDF) and hemicellulose of Rhodes grass hay were approximately $75 \%$ and $32.5 \%$ of that calculated for SPT1, SPT2, SPT3 and SPT4. The steam treatment of spartina grass hay at high pressure (15 par / min) resulted in drastic changes of fiber fraction contents and that ADF, cellulose and lignin were increased (Castro, et al., 1995, Castro, et al. 1994 and Broderick, et al., 1993). The same observation was obtained by Fadel (1992) with Lucerne heated to $20 \mathrm{hr}$ at $100^{\circ} \mathrm{C}$. In contrast, Rai and Mudgal (1987) reported that there was insignificant changes for all fiber fractions of steamed rice straw at $2 \mathrm{~kg} / \mathrm{cm}^{2}$ for $2 \mathrm{hr}$.

The NDF, hemicellulose and silica of steamed spartina grass hay (SPT5) appreciably decreased $v s$. non-steamed saprtina grass hay a result which agrees with the findings of Zelenak et al. (1990) and only partially regarding hemicellulose with that reported by Hagemeister and Ahrens (1986), Broderick et al. (1993) and Castro, et al. (1995). 
The most remarkable change caused by steam treatment was the extensive hydrolization of hemicellulose and the remained material consisting mainly of cellulose and lignin (Zelenak et al., 1990 and Castro et al., 1995). In addition, the acid detergent insoluble nitrogen (ADIN) was doubled in spartina grass hay by steam treatment as that reported by (Fadel, 1992, Broderick et al., 1993, Castro et al., 1994, and Nishino et al., 1994). The sodium content of spartina grass hay varied from 7 to10 times than that determined for Rhodes grass hay, while all the other minerals; potassium, calcium, magnesium, phosphorus, copper, iron, manganese, zinc, cadmium and lead were almost comparable for all treated spartina and Rhodes grass hay as shown in Table 1.

\section{In Situ DM and CP degradation}

The data obtained from in situ degradation (Table 2) indicated that there was slight significant difference $(\mathrm{P}<.05)$ among SPT1, SPT2, SPT3, and SPT4 in DM degradation up to $24 \mathrm{hr}$ of incubation but significantly higher difference for those calculated for both Rhodes grass hay (RH) and steamed spartina (SPT5). From $24 \mathrm{hr}$ up to $48 \mathrm{hr}$, there was a slight increase of DM degradation for SPT1, SPT2, SPT3 and SPT4 but significant differences were still observed among them especially SPT1 which was very slowly increased. However, both (RH) and (SPT5) insignificantly differed and were sharply increased but still significantly $(\mathrm{P}<.05)$ lower than SPT1, SPT2, SPT3 and SPT4. After $72 \mathrm{hr}$ of incubation, all the treatments recorded very slight increases except for (RH) which showed an accelerating increase but was still significantly $(\mathrm{P}<.05)$ lower than SPT2, SPT3 and SPT4 and did not significantly differ from SPT1 and SPT5. At $96 \mathrm{hr}$., RH showed insignificant DM degradation compared with SPT2, SPT3 and SPT4, and consequently a wide significant difference between $(\mathrm{RH})$ and both SPT1 and SPT5 were detected. At the end of incubation period, DM degradation of RH was extremely the highest compared to the other treatments which tended to show stable degradability after $72 \mathrm{hr}$ of incubation.

Table 2. In Situ dry matter degradation of Rhodes grass hay vs. spartina grass hay in cannulated camels

\begin{tabular}{|c|c|c|c|c|c|c|c|}
\hline \multirow{2}{*}{$\begin{array}{l}\text { Time } \\
\text { (hr) }\end{array}$} & \multicolumn{6}{|c|}{ DM Degradation, $\%$} & \multirow{2}{*}{$\pm \mathbf{S E}$} \\
\hline & Rhodes & SPT1 & SPT2 & SPT3 & SPT4 & STP5 & \\
\hline 6 & $2.0^{\mathrm{d}}$ & $10.5^{\mathrm{bc}}$ & $13.4^{\mathrm{ab}}$ & $12.2^{\mathrm{ab}}$ & $13.8^{\mathrm{a}}$ & $8.0^{\mathrm{c}}$ & 0.96 \\
\hline 12 & $7.9^{\mathrm{c}}$ & $18.4^{\mathrm{a}}$ & $22.3^{\mathrm{a}}$ & $18.5^{\mathrm{a}}$ & $20.4^{\mathrm{a}}$ & $13.0^{\mathrm{b}}$ & 1.62 \\
\hline 24 & $14.3^{c}$ & $29.3^{b}$ & $34.8^{\mathrm{a}}$ & $32.0^{\mathrm{ab}}$ & $35.8^{\mathrm{a}}$ & $15.6^{\mathrm{c}}$ & 1.30 \\
\hline 48 & $29.6^{\mathrm{c}}$ & $36.0^{\mathrm{b}}$ & $43.7^{\mathrm{a}}$ & $41.1^{\mathrm{ab}}$ & $44.0^{\mathrm{a}}$ & $29.8^{\mathrm{c}}$ & 1.81 \\
\hline 72 & $38.2^{\mathrm{b}}$ & $38.0^{\mathrm{b}}$ & $45.9^{\mathrm{a}}$ & $43.8^{\mathrm{a}}$ & $45.2^{\mathrm{a}}$ & $34.6^{\mathrm{b}}$ & 1.76 \\
\hline 96 & $45.7^{\mathrm{a}}$ & $39.6^{\mathrm{b}}$ & $46.6^{\mathrm{a}}$ & $44.5^{\mathrm{a}}$ & $45.3^{\mathrm{a}}$ & $34.8^{\mathrm{c}}$ & 0.95 \\
\hline 120 & $49.1^{\mathrm{c}}$ & $48.4^{\mathrm{a}}$ & $54.1^{\mathrm{b}}$ & $44.3^{b}$ & $36.0^{\mathrm{c}}$ & $27.4^{\mathrm{b}}$ & 0.59 \\
\hline
\end{tabular}

Means in the same row followed by different letters differ significantly $(\mathrm{P}<.05)$.

It could be concluded from the in situ experiment that the DM degradation of RH was started very low and went slowly up to $24 \mathrm{hr}$ and vise versa for SPT2, SPT3 and SPT4. After $24 \mathrm{hr}$, the degradability pattern was inversed, but the same DM degradability percent was obtained for SPT2 and SPT4 vs. RH at 48 and $96 \mathrm{hr}$, respectively. The high DM degradability of SPT2 and SPT4 vs RH could be understood through the fiber fractions content in Table 1, where the easy degradable 
fiber fraction (hemicellulose) of SPT2 and SPT4 is almost 4 times that of RH and vise versa for the hard degradable fractions (lignin and cellulose) which were approximately 2 times in RH comparing with SPT2 and SPT4.

Crude protein degradation as shown from Table 3 indicated that there were significant differences among SPT2, SPT3 and SPT4 and the other treatments at $6 \mathrm{hr}$ of incubation. The CPD of SPT2 was significantly the highest compared with the other treatments for all incubation times followed by SPT3. Rhodes grass degradable protein showed the same trend noticed with DMD having slow degradability up to 24 hrs and then gone faster up to $96 \mathrm{hr}$, but recorded the lowest CP degradation vs the other treatments. The more reasonable explanation for this result is that the high degradation of easy degradable fibers for SPT2 and SPT3 assist the rumen microflora to use the energy produced to utilize the degraded crude protein at early hours of incubation and vise versa for CPD of Rhodes grass hay where energy utilization stared later. At $24 \mathrm{hr}$ of incubation, the CPD percent of SPT2, SPT3 and SPT4 was approximately 5.1, 4.0 and 3.9 times as that of $\mathrm{RH}$, respectively. At $48 \mathrm{hr}$ of incubation, the ratio became $2.1,1.9$ and 1.9 times, respectively, while, at $72 \mathrm{hr}$ of incubation, the ratio was $1.6,1.5$ and 1.3 times, respectively.

Table 3. In Situ crude protein degradation of Rhodes grass hay vs. spartina grass hay in cannulated camels

\begin{tabular}{|c|c|c|c|c|c|c|c|}
\hline \multirow{2}{*}{$\begin{array}{c}\text { Time } \\
\text { (hr) }\end{array}$} & \multicolumn{6}{|c|}{ CP Degradation, $\%$} & \multirow{2}{*}{$\pm \mathbf{S E}$} \\
\hline & Rhodes & SPT1 & SPT2 & SPT3 & SPT4 & STP5 & \\
\hline 6 & $1.4^{\mathrm{c}}$ & $4.2^{\mathrm{b}}$ & $5.4^{\mathrm{ab}}$ & $6.5^{\mathrm{a}}$ & $6.8^{\mathrm{a}}$ & $0.74^{\mathrm{c}}$ & 1.85 \\
\hline 12 & $2.7^{\mathrm{d}}$ & $8.6^{\mathrm{b}}$ & $16.8^{\mathrm{a}}$ & $9.7^{\mathrm{b}}$ & $9.2^{\mathrm{b}}$ & $4.71^{\mathrm{c}}$ & 2.11 \\
\hline 24 & $5.2^{\mathrm{c}}$ & $16.0^{\mathrm{b}}$ & $26.4^{\mathrm{a}}$ & $20.8^{b}$ & $20.5^{\mathrm{b}}$ & $6.5^{\mathrm{c}}$ & 1.54 \\
\hline 48 & $15.5^{\mathrm{d}}$ & $23.2^{\mathrm{bc}}$ & $33.0^{\mathrm{a}}$ & $28.9^{\mathrm{ab}}$ & $27.7^{\mathrm{ab}}$ & $20.2^{\mathrm{cd}}$ & 2.05 \\
\hline 72 & $21.9^{c}$ & $25.1^{\mathrm{c}}$ & $35.8^{\mathrm{a}}$ & $32.4^{\mathrm{ab}}$ & $29.2^{\mathrm{b}}$ & $24.9^{c}$ & 1.10 \\
\hline 96 & $25.2^{\mathrm{b}}$ & 26.5 & $36.5^{\mathrm{a}}$ & $33.2^{\mathrm{a}}$ & $28.2^{\mathrm{b}}$ & $25.2^{\mathrm{b}}$ & 1.43 \\
\hline 120 & $26.1^{\mathrm{b}}$ & $37.3^{\mathrm{a}}$ & $33.3^{\mathrm{a}}$ & $27.4^{\mathrm{b}}$ & $26.4^{\mathrm{b}}$ & $26.3^{\mathrm{b}}$ & 1.37 \\
\hline
\end{tabular}

Means in the same row followed by different letters differ significantly $(\mathrm{P}<.05)$.

Concerning the effect of steam treatment on DM and CP degradability values, both of them were significantly lower compared with the untreated spartina hay due to the increase of digestible nitrogen loss which associated with fiber composing acid detergent insoluble nitrogen (ADIN) complex as described by Castro et al. (1994). Nishino et al. (1994) who reported that IVDMD and in situ CPD were significantly decreased by heating alfalfa hay at $120^{\circ} \mathrm{C}$ and this trend was confirmed by the findings of Kaankuke et al. (1996) who found that nitrogen degradability of full fat soybean was decreased by cooking at $100^{\circ} \mathrm{C} / 15$ min. Broderick et al. (1993) reported that in vitro degradation was decreased by heat treatment of alfalfa hay. On the other hand there is another suggestion that steam treatment produces some anti-nutritional factors resultant from Brown reaction or Millard reaction like furfural which has irritant effect for the mucosal membrane of animal's nose. (Irvin, 1980 and Castro et al. 1994).

Millard reaction products had an adverse effect on rumen microbes viability and protecting protein from microbial degradation and in some cases decrease the volatile fatty acids production (Kostyukovsky and Marounek, 1995). In Contrast, Raiy and Mudgal (1987 reported slight improvement of rice straw IVDMD by steam treatment 
( $2 \mathrm{~kg} / \mathrm{cm}^{2} / 2 \mathrm{hr}$ ). The present results also coincide with the findings of Zelenak et al., 1990 who reported that in situ DMD of barley straw and other fibrous byproducts was significantly increased by steam treatment. Values of low protein degradability at $120 \mathrm{hr}$ compared with $96 \mathrm{hr}$ of incubation time might be attributed to influx of microbial populations as they possibly can modify degradation conditions based on the bag pore size as indicated by Michalet-Doreau and Ould-Bah (1992).

\section{In Situ NDF and ADF degradation:}

The in situ degradation pattern for NDF and ADF of SPT1, SPT2, SPT3, SPT4, and SPT5 at 6, 12, 24, 48, 72 and $96 \mathrm{hr}$ of incubation was almost the same as that shown in Tables 4 and 5. However, NDF and ADF degradation of SPT5 at $24 \mathrm{hr}$ was significantly lower vs SPT1, SPT2, SPT3, and SPT4, but a sharp increase occurred at $48 \mathrm{hr}$ to match with the previous treatments. On the other hand, the NDF and ADF degradability values of Rhodes grass hay $(\mathrm{RH})$ were significantly $(\mathrm{P}<.05)$ lower than the other treatments at similar incubation intervals.

Table 4. In Situ NDF degradation of Rhodes grass hay vs. spartina grass hay in cannulated camels

\begin{tabular}{|c|c|c|c|c|c|c|c|}
\hline \multirow{2}{*}{$\begin{array}{l}\text { Time } \\
\text { (hr) }\end{array}$} & \multicolumn{6}{|c|}{ NDF Degradation, $\%$} & \multirow{2}{*}{$\pm \mathbf{S E}$} \\
\hline & Rhodes & SPT1 & SPT2 & SPT3 & SPT4 & STP5 & \\
\hline 6 & $0.9^{\mathrm{b}}$ & $13.3^{\mathrm{a}}$ & $14.7^{\mathrm{a}}$ & $11.2^{\mathrm{a}}$ & $13.6^{\mathrm{a}}$ & $18.4^{\mathrm{a}}$ & 2.17 \\
\hline 12 & $8.5^{\mathrm{b}}$ & $30.1^{\mathrm{a}}$ & $29.0^{\mathrm{a}}$ & $23.5^{\mathrm{a}}$ & $24.3^{\mathrm{a}}$ & $27.4^{\mathrm{a}}$ & 2.59 \\
\hline 24 & $16.3^{\mathrm{c}}$ & $45.8^{\mathrm{a}}$ & $51.2^{\mathrm{a}}$ & $47.5^{\mathrm{a}}$ & $50.1^{\mathrm{a}}$ & $31.1^{\mathrm{b}}$ & 2.41 \\
\hline 48 & $34.7^{\mathrm{b}}$ & $62.2^{\mathrm{a}}$ & $62.9^{\mathrm{a}}$ & $62.8^{\mathrm{a}}$ & $62.2^{\mathrm{a}}$ & $59.6^{\mathrm{a}}$ & 2.78 \\
\hline 72 & $45.0^{\mathrm{b}}$ & $65.7^{\mathrm{a}}$ & $66.0^{\mathrm{a}}$ & $66.9^{\mathrm{a}}$ & $64.4^{\mathrm{a}}$ & $68.8^{\mathrm{a}}$ & 2.58 \\
\hline 96 & $54.7^{\mathrm{b}}$ & $69.0^{\mathrm{a}}$ & $67.6^{\mathrm{a}}$ & $68.2^{\mathrm{a}}$ & $65.4^{\mathrm{a}}$ & $69.5^{\mathrm{a}}$ & 1.30 \\
\hline 120 & $58.9^{\mathrm{d}}$ & $68.3^{\mathrm{b}}$ & $96.1^{\mathrm{b}}$ & $69.7^{\mathrm{ab}}$ & $64.1^{\mathrm{c}}$ & $71.7^{\mathrm{a}}$ & 0.78 \\
\hline
\end{tabular}

Means in the same row followed by different letters differ significantly $(\mathrm{P}<.05)$.

Table 5. In Situ ADF degradation of Rhodes grass hay vs. spartina grass hay in cannulated camels

\begin{tabular}{|c|c|c|c|c|c|c|c|}
\hline \multirow{2}{*}{$\begin{array}{c}\text { Time } \\
\text { (hr) }\end{array}$} & \multicolumn{6}{|c|}{ ADF Degradation (\%) } & \multirow{2}{*}{$+\mathbf{S E}$} \\
\hline & Rhodes & SPT1 & SPT2 & SPT3 & SPT4 & STP5 & \\
\hline 6 & $1.5^{\mathrm{b}}$ & $1.2^{\mathrm{b}}$ & $13.6^{\mathrm{a}}$ & $13.5^{\mathrm{a}}$ & $13.6^{\mathrm{a}}$ & $12.2^{\mathrm{a}}$ & 2.72 \\
\hline 12 & $4.5^{\mathrm{b}}$ & $8.5^{\mathrm{b}}$ & $26.8^{\mathrm{a}}$ & $23.0^{\mathrm{a}}$ & $25.1^{\mathrm{a}}$ & $21.4^{\mathrm{a}}$ & 2.96 \\
\hline 24 & $13.7^{\mathrm{c}}$ & $23.2^{\mathrm{b}}$ & $44.4^{\mathrm{a}}$ & $43.9^{\mathrm{a}}$ & $47.9^{\mathrm{a}}$ & $26.9^{\mathrm{b}}$ & 2.40 \\
\hline 48 & $35.5^{b}$ & $39.1^{b}$ & $55.8^{\mathrm{a}}$ & $56.7^{\mathrm{a}}$ & $59.7^{\mathrm{a}}$ & $55.8^{\mathrm{a}}$ & 3.24 \\
\hline 72 & $46.1^{\mathrm{b}}$ & $42.9^{\mathrm{b}}$ & $57.8^{\mathrm{a}}$ & $60.9^{\mathrm{a}}$ & $61.5^{\mathrm{a}}$ & $64.1^{\mathrm{a}}$ & 2.14 \\
\hline 96 & $46.2^{\mathrm{b}}$ & $47.0^{\mathrm{b}}$ & $60.4^{\mathrm{a}}$ & $62.1^{\mathrm{a}}$ & $63.4^{\mathrm{a}}$ & $65.1^{\mathrm{a}}$ & 3.30 \\
\hline 120 & $61.6^{\mathrm{b}}$ & $45.6^{\mathrm{c}}$ & $61.4^{\mathrm{b}}$ & $63.5^{\mathrm{ab}}$ & $62.2^{\mathrm{b}}$ & $67.1^{\mathrm{a}}$ & 1.28 \\
\hline
\end{tabular}

Means in the same row followed by different letters differ significantly $(\mathrm{P}<.05)$

The increase of NDF degradability values of spartina was 1.16 times $v s$. RH at $6,12,24,48,72,96$ and $120 \mathrm{hr}$, respectively. While, ADF increases were 6.48, 4.67, $2.72,1.70,1.25,1.29$ and 0.97 times vs. RH at 6, 12, 24, 48, 72, 96 and $120 \mathrm{hr}$, respectively. In addition, the depression of Rhodes NDF and ADF degradation at 24 $\mathrm{hr}$ was associated with the depression of $\mathrm{CP}$ degradability at the same time as shown 
in Tables 3, 4 and 5. Regarding the impact of steam pressure treatment of spartina hay (SPT5) on NDF and ADF degradation; there was insignificant influence except for at $24 \mathrm{hr}$ which significantly $(\mathrm{P}<.05)$ declined compared with SPT1, SPT2, SPT3 and SPT4. The present results agree with the findings of Kostyukousky and Marounek (1995) who indicated that the Millard reaction products (MRPs) generated by autoclaving may decrease availability of sugars in feedstuffs for microorganisms as an easy source of energy.

Also Fedel (1992) and Deinum and Maassen (1994) demonstrated that drying of ryegrass and maize silage at $105^{\circ} \mathrm{C}$ significantly decreased in vitro cell wall content disappearance (IVCWCD) and that the prolonged heat was detrimental to the nutritive value of lucerne and almond hulls. In contrast, Castro, et al. (1995) stated that steam treatment of eucalyptus significantly improved CWCD by rumen microbes. Degradability of CF was significantly increased by steam pressure $(1 \mathrm{~kg} /$ $\mathrm{cm} 2 / 1 \mathrm{hr}$ ) of wheat straw (Rai and Mudgal, 1988) and by heating of rice straw at $190^{\circ} \mathrm{C} / 10-16$ min. / 12 Par as concluded by Hagemeister and Ahrens (1986). Rai and Mudgal (1986) and Zelenak, et al. (1990) confirmed those that in vitro ADF, NDF, cellulose and hemicellulose digestibilities were significantly increased when the poor quality roughage was treated with steam pressure. Insignificant changes of ADF and NDF digestibility after steam treatment were reported by Zhao et al. (1996) and Rai and Mudgal (1987).

\section{In vitro gas production}

The data obtained from gas production showed a different pattern from that found from in situ DM, CP, NDF and ADF degradation as shown in Table 6.

Table 6. In Vitro gas production ( $\mathrm{ml} / 0.20 \mathrm{~g} \mathrm{DM})$ of Rhodes grass hay vs. spartina grass hay

\begin{tabular}{cccccccc}
\hline $\begin{array}{c}\text { Time } \\
\text { (hr) }\end{array}$ & Rhodes & SPT1 & SPT2 & SPT3 & SPT4 & STP5 & \multirow{2}{*}{ \pm SE } \\
\cline { 2 - 6 } & SPS Production, ml & \\
\hline $\mathbf{3}$ & 1.3 & 1.3 & 0.7 & 0.7 & 1.3 & 1.3 & 0.72 \\
$\mathbf{6}$ & $4.0^{\mathrm{ab}}$ & $3.3^{\mathrm{b}}$ & $4.0^{\mathrm{ab}}$ & $4.0^{\mathrm{ab}}$ & $3.3^{\mathrm{b}}$ & $5.3^{\mathrm{a}}$ & 0.52 \\
$\mathbf{1 2}$ & $8.0^{\mathrm{b}}$ & $6.0^{\mathrm{c}}$ & $8.7^{\mathrm{b}}$ & $4.7^{\mathrm{d}}$ & $8.7^{\mathrm{b}}$ & $10.3^{\mathrm{a}}$ & 0.39 \\
$\mathbf{2 4}$ & $20.3^{\mathrm{b}}$ & $16.3^{\mathrm{c}}$ & $17.7^{\mathrm{bc}}$ & $12.0^{\mathrm{d}}$ & $17.0^{\mathrm{c}}$ & $25.3^{\mathrm{a}}$ & 1.00 \\
$\mathbf{4 8}$ & $37.0^{\mathrm{a}}$ & $24.0^{\mathrm{b}}$ & $28.3^{\mathrm{b}}$ & $18.3^{\mathrm{c}}$ & $27.3^{\mathrm{b}}$ & $34.0^{\mathrm{a}}$ & 1.32 \\
$\mathbf{7 2}$ & $43.7^{\mathrm{a}}$ & $24.7^{\mathrm{cd}}$ & $31.0^{\mathrm{b}}$ & $22.0^{\mathrm{d}}$ & $30.0^{\mathrm{bc}}$ & $36.0^{\mathrm{b}}$ & 1.85 \\
\hline
\end{tabular}

Means in the same row followed by different letters differ significantly $(\mathrm{P}<.05)$

Gas production $(\mathrm{ml})$ of all treated spartina insignificantly differ at $3 \mathrm{hr}$ of incubation, whereas at 6,12 and $24 \mathrm{hr}$ the value of gas produced by SPTS was significantly $(\mathrm{P}<.05)$ higher than the other treatments. Comparing Rhodes grass hay with the other treatments (with exception of STP5), the measured gas indicated that there were insignificant changes up to $12 \mathrm{hr}$, but an obvious significant increased of gas volume was measured from $24 \mathrm{hr}$ up to $72 \mathrm{hr}$ of incubation. The gas production profile of RH and SP5 is almost the same as in in situ DM, CP, NDF and ADF all of which appreciably increased after $24 \mathrm{hr}$ of incubation. The closest gas production to RH and SPT5 was SPT2 and SPT4. The present results concerning the effect of steam treatment on gas production is confirmed by the results of Castro et al. (1994) who indicated that the volume of gas produced after $48 \mathrm{hr}$ of steamed wheat straw 
(19 par / 3 min. $/ 120^{\circ} \mathrm{C}$ ) was $160.4 \%$ of control, compared to $41.6 \%$ in the present investigation.

Zelenak, et al. (1990), Broderick, et al. (1993) and Zhao et al. (1996) stated that insignificant changes occurred in ruminal total volatile fatty acids of livestock fed an heated or steamed roughages.

\section{CONCLUSION}

Based on the approximate analysis and in situ nutrient degradation and in vitro gas production it could be concluded that; SPT2, SPT3 and SPT4 were always the best for in situ DM, CP, NDF and ADF degradability. As a result of washing and steam treatment, the total ash content was reduced in SPT2, SPT4 and SPT5 by $30 \%$ in average. So there is no need to do the steam treatment which is sometimes expensive and not applicable. Hemicellulose of spartina grass is considerably higher than Rhodes grass, accordingly the cellulose and lignin of Rhodes hay is higher compared with saprtina hay, speculating that spartina is more fermentable as indicated by in vitro gas production. Additional in vivo experiments and palatability studies are required to carry out on spartina grass hay to be approved as nonconventional feed resource for livestock in arid lands and coastal regions.

\section{REFERENCES}

Ahmed, R. and S. Ismail, 1993. Studies on selection of salt tolerant plants for food, fodder and fuel from world flora. Towards the rational use of high salinity tolerant lants. Vol. 2: 295-300, Kluwer Academic Publishers, Netherlands.

A.O.A.C., 1984. Official Methods of Analysis. Assoc. Offic. Anal. Chem., (14 ${ }^{\text {th }}$ ed.) Washington, D. C. 20044.

Aronson, J.A., 1989. HALOPH 'A Data Bases of Salt Tolerant Plants of the World". Office of Arid Lands Studies, The University of Arizona, Tucson, Arizona. USA.

Ben Salem, H., A. Nefzaui, and H. Abdouli, 1994. Palatability of shrubs and fodder trees measured on sheep and dromedaries, L Mthadological approach. Animal Feed Science and Technology, 46: 143-153.

Broderick, G. A., J. H. Yang and R. G. Koegel, 1993. Effect of steam heating alfalfa hay on utilization by lactating dairy cows. J. Dairy Sci., 76: 165-174.

Castro, F. B., P. M. Hotten, E. R. Ørskov and M. Rebeller, 1994. Inhibition of rumen microbes by compounds formed in the steam treatment of wheat straw. Bioresource Technology 50, 25-30.

Castro, F. B., T. C. B. Paiva and Jr. I. Arcaro, 1995. Substitution of sugar cane with steam treated eucalyptus (Eucalyptus grandis): effects on intake and growth rate or dairy heifers. Animal Feed Science and Technology, 52: 93-100.

Chapman, D. H. and F. P. Pratt, 1961. Methods of analysis for soils, plants and waters. University of California, Division of Agricultural Sciences.

Deinum, B. and A. Maassen, 1994. Effects of drying temperature on chemical composition and in vitro digestibility of forages. Animal Feed Science and Technoloyg, 46: 75-86.

Fadel, J. G., 1992. Evaluation of chemical composition, optical density measurements and in Sacco disappearance of two commodities under controlled 
moisture and heating conditions. Animal Feed Science and Technoloyg, 36: 1327.

Garduno, M.A., 1993. Kochia: A new alternative forage under high salinity conditions of Mexico. Towards the rational use of of high salinity tolerant plants. Vol. 1: 459 - 464, Kluwaer Academic Publishers, Netherlands.

Glenn, E. P., W. E. Coates, J.J. Riley, R.C. Kuehl and R.S. Swingle, 1992. Salicronia bigelovii Torr.: A sea water irrigated forage for goats. Animal Feed Science and Technology 40: 21-30.

Goering, H.K and P. J. Van Soest, 1970. Forage Fiber Analyses (Apparatus, Reagents, Procedures and Some Applications). Washington, D. C. Agricutural Research Service, USDA. 19p. Agricu. Handbook, 379.

Hagemeiser, H. and F. Ahrens, 1986. Verdaulichkeit and Futteraufnahme Von Bagasse, Verschiedenen Stroharten and Annas - sowie Bananemblattern nach Dampfdruckbehandlung beim Wiederkauer. J. Anim. Physiol. and Nutr. 55: 134143.

Hamaad, S.M.S., 2000. Plant physiology under stress conditions and adverse circumstances. Faculty of Agriculture, Cairo University (Arabic Text Book).

Hubbard, D. F. and B. Arvid 1988. IVDDM and chemical constituents in selected species of wet land plants. Proc. S. D. ACAD., Vol. 67, 44-58.

Irvin, E. L., 1980. Toxic Constituents of Plant Foodstuffs ( $2^{\text {nd }}$ ed.) Academic press, Fifth Avenue, New York 10003, USA.

Kaankuka, F. G., T. F. Balogun and T. S. B. Tegbe, 1996. Effects of duration of cooking of full-fat soyabeans on proximate analysis, levels of antinutritional factors, and digestibility by weanling pigs. Animal Feed Science and Technology, 62: 229-237.

Katting, R.M., J.W. Winder, J.D. Wallace, and C.C. Bailey, 1993. Evaluation of biological efficiency of free-grazing beef cows under semi-desert conditions. J. Animal Sci., 71: 2601-2607.

Kostyukovsky, V. and M. Marounek, 1995. Maillard reaction products as a substrate in in-vitro rumen fermentation. Animal Feed Science and Technology, 55: 201206.

Lieth, H. and A. Lieth, 1993. Sea water irrigation studies in the United Arab Emirates; an introduction to the Al Ain Conference. Towards the rational use of high salinity tolerant plants. Vol. 1: 1-10. Kluwer Academic Publishers, Netherlands.

Mehrez, A. Z. and G. R. Ørskov, 1977. A study of the artificial fiber bag technique for determining the digestibility of feeds in the rumen. J. Agric., Sci., Cambridge, 88: 645-650.

Menke, K., L. Raab, A. Salewski, H. Steingass, D. Fritz, and W. Schneider, 1979. The estimation of digestibility and meabolizable energy content of ruminant feeding stuffs from the gas production when they are incubated with rumen liquor in vitro. J. Agric. Sci., Camb., 93: 217-222.

Menk, K.H. and H. Steingass, 1988. Estimation of the energetic feed value obtained from chemical analysis and in vitro gas production using rumen fluid. Animal Research and Development, 28: 7-55.

Michalet-Doreau B. and M.Y. Ould-Bah 1992. In vitro and in sacco methods for the estimation of dietary nitrogen degradability in the rumen: a review. Animal Feed Science and Technology, 40:57-86. 
Nishino, N., S. Uchida, and M. Ohshima, 1994. Ruminal degradation of alfalfa protein as influenced by sodium hydroxide and heat treatment. Animal Feed Science and Technology, 48: 131-141.

Nissen, O., 1989. MSTAT 4. Michigan State Univ., Statistical package. Dept. of Crop and Soil Science Michigan State Univ., E. Lansing, Michigan 48824. USA.

O'leary, J.W. and E.P. Gleen, 1994. Global distribution and potential of for halophytes. V.R. Squires and A.T. Ayoub (eds.), halophytes as a source for livestock and for rehabilitation of degraded lands, Ch.2. Kluwaer Academic Publishers, Netherlands.

Ørskov, E.R. 1989. Recent Advances in Evaluation of Roughages as Feeds for Ruminants. In advances in animal nutrition (ed. D.J. Farell), pp. 102-108. University of New England Printery, Armidale.

Rai, S. N. and V. D. Mudgal, 1986. Effects of alkali and steam pressure treatments on compositional changes and in vitro fibber digestibility of rice straw. Indian J. Anim. Nutr., 3: 95-101.

Rai, S. N. and V. D. Mudgal, 1987. Associative effect of $\mathrm{NaOH}$ and steam pressure treatment on chemical composition of rice straw and its fibber digestibility in rumen. Indian J. Anim. Untr., 4: 5-11.

Rai, S. N., and V. D. Mudgal., 1988. Effects of cellulose, alkali and/or steam, treatments of wheat straw on intake, digestibility and balances of minerals in goats. Biological wastes, 24: 175-185.

Riley, James J. and M. Abdalla, 1993. Preliminary evaluation of salicornia production and utilization in Kuwait. Towards the rational use of of high salinity tolerant plants. Vol. 2: 319-329, Kluwaer Academic Publishers, Netherlands.

Zelenak, I., K. Boda, D. Jalc, J. Bucko and R. Apalovic, 1990. Utilization of secondary wood resources in ruminant nutrition. Arch. Anim. Nutr., Berlin, 40: 115.

Zhao, Y., K. Taniguchi and T. Obitsu, 1996. Effects of different processing procedures for rice bran on dietary nutrient digestion in each segment of digestive tract of steers. Animal Feed Science and Technology, 59: 265-277. 


\section{تكسير المادة الجافة والألياف الخام بطريقة أكياس النايلون وإنتاج الغاز معملياً لحشيشة المروية بماء البحر بكرش الإبل العربية (Spartina alterniflora Lois.)}

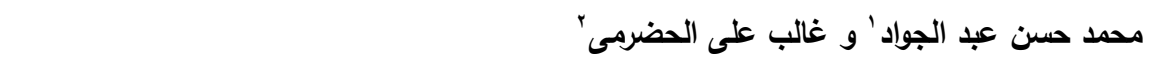

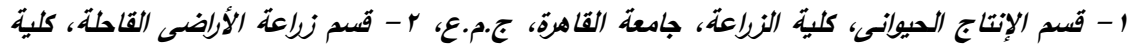

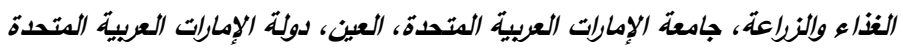

هدفت الدراسة إلى تقييم القيمة الغذائية لحشيشة (Spartina alterniflora Lois. المروية بماء البحر

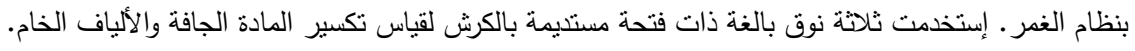

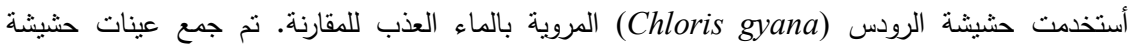
SPT1 Spartina

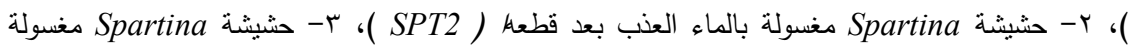

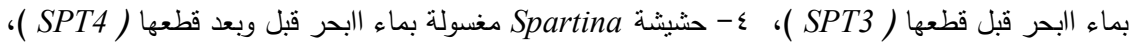

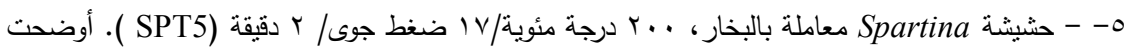

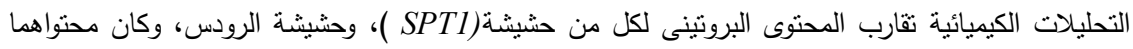

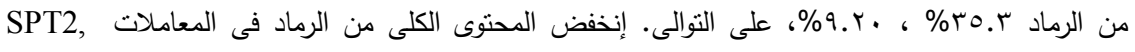
SPT4, SPT5

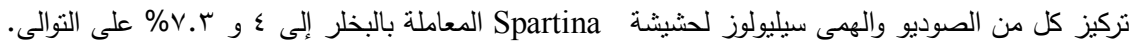

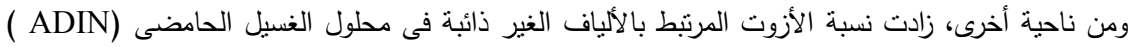

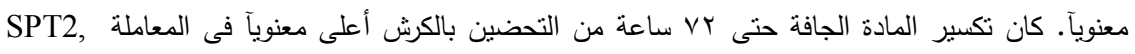

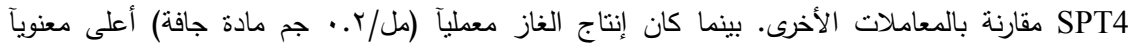

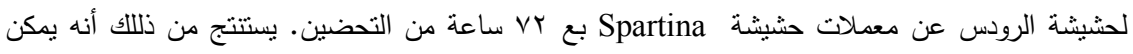

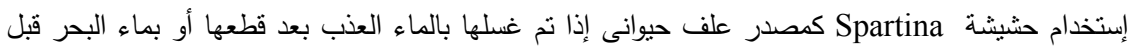

